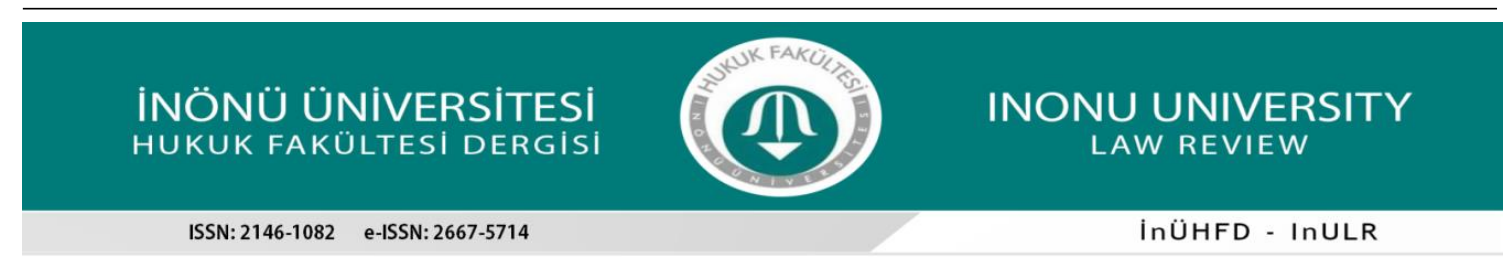

\title{
AŞKIN ZARARIN İSPATI do
}

\author{
PROOF OF EXCESSIVE DAMAGE
}

\begin{abstract}
Yıldırım KESER*
Makale Bilgi

Gönderilme: 05/05/2020

Kabul: 15/09/2020

\section{Anahtar Kelimeler}

Aşkın Zarar, Borçlunun Kusuru, Temerrüt Faizi, Soyut Yöntem, Somut Yöntem.

\section{Özet}

Para borçları, borçlanılan tutarı ifade eder. Borçlu, borçlandığı nominal değeri öderse, para borcunu ifa etmiş sayılır. Para borçlusu temerrüde düşerse, temerrüt faizinden sorumlu olur. Paranın satın alma gücünün zamanla azaldığı ekonomik düzenlerde temerrüt faizi ile karşılanmayan zararlar ortaya çıkmaktadır. Temerrüt faizi ile karşılanamayan zararlar, aşkın zarar olarak nitelendirilir. Aşkın zararın varlığını alacaklı ispat etmelidir. Aşkın zararın ispatında hangi yöntemin uygulanması gerektiği konusunda yasal bir düzenleme yoktur. $\mathrm{Bu}$ zarar türünün ispatında somut ve soyut yöntem olmak üzere iki farklı ispat yöntemi vardır. Somut yöntemde, alacaklı zararını somut olarak ispat etmek zorundadır. Soyut yöntemde ise, alacaklı, paranın değer kaybetmesini gerekçe göstererek zararını talep edebilir. Bu yöntemde alacaklının fiili karinelerden yararlanarak zararının miktarını ispat edebilmesi mümkündür. Türk Hukuku'nda aşkın zararın ispatı konusunda hangi yöntemin uygulanması gerektiği konusunda görüş birliği yoktur. Yöntemlerin uygulanmasında ilkelerin geliştirilmesi gerekir. Bu nedenle de borcun kaynağı üzerinde durulmalıdır. Somut yöntem, sözleşmeden doğan para borçlarının temerrüdü hâlinde ortaya çıkan aşkın zarar iddiasının ispatında uygulanmalıdır. Soyut yöntem ise haksız fiilden, sebepsiz zenginleşmeden ve gerçek olmayan vekâletsiz iş görmeden doğan borçlardan kaynaklanan aşkın zararın ispatı için uygulanması gereken yöntemdir.
\end{abstract}

\section{Article Info}

Received: 05/05/2020 Accepted: 15/09/2020

\section{Keywords}

Excessive Damage, Debtor's Fault, Default Interest, Substantial Method, Concrete Method.

\begin{abstract}
Pecuniary debts signify the amount of money that has been owed. If the debtor pays the nominal value, he fulfils his debt. If the debtor goes into default, he becomes responsible of the interest. In economic systems, where the value of money decreases in time, damages that can not be covered by the default interest may occur. Those damages are considered to be excessive damages. The burden of proof for the existence of such damage is on the debtee. There is no legal regulation stating which method will be used to prove such damage. To prove such damages there are two different methods, namely substantial method and concrete methods. According to the concrete method the debtee has to prove his damage. According to the substantial method however, the debtee may claim his damages on the grounds of erosion of money. In this method the debtee may prove the amount of the damage using the presumptions of fact. In Turkish law, there's no consensus on which method shall be used to prove the excessive damage. Principles on the usage of methods have to be developed. Therefore the source of the debt has to be emphasized. Concrete method should be applied to prove the excessive damage, when the damage occurs in case of default of pecuniary debts arising from conventional obligation. Substantial method however, should be applied to prove the excessive damage caused by debts arising from tort, unjust enrichment and notional negotiorum gestio.
\end{abstract}




\section{GİRIŞ}

Paranın çeşitli nedenlerden dolayı değer kaybetmesi önemli bir ekonomik sorundur. Para borcunu ifada temerrüde düşen borçlu işlemiş temerrüt faizinden sorumludur. Temerrüt faizi ile karşılanmayan zararlar şartları varsa aşkın zarar kapsamında değerlendirilebilir.

Aşkın zararın ispatı, Türk Hukuku'nda uzun yıllardır tartışmalı olan bir konudur. Anayasa Mahkemesi'nin 21.12.2017 tarihli ve 2014/2267 E. sayılı kararından sonra aşkın zararın ispatı konusunda Yargıtay Hukuk Daireleri arasında görüş ayrılıkları ortaya çıkmıştır. Mevcut durum uygulama açısından belirsizliklere sebep olmaktadır.

Aşkın zararın ispatında somut ve soyut yöntem olmak üzere iki farklı yöntem vardır. $\mathrm{Bu}$ yöntemlerin hangi hallerde uygulanması gerektiğine ilişkin temel ilkelerin belirlenmesi gerekir.

\section{AŞKIN ZARARIN TANIMI, HUKUKİ NITTELİĞİ VE ŞARTLARI}

\section{A. Tanımı}

Aşkın zarar, temerrüt faizini aşan zararları ifade eder. Aşkın zarar, yalnızca para alacaklarından kaynaklanır. Temerrüde düşen borçlu, temerrüde düşmekte hiçbir kusuru olmadığını ispat ederse, aşkın zararı tazmin borcundan kurtulur (TBK md 122, eBK md 105). Aşkın zarar, borçlu temerrüde düşmeden borcunu ödemiş olsaydı, alacaklının mal varlığının durumu ile temerrüt sonucunda ortaya çıkan ve oluşan durum arasındaki farktır ${ }^{1}$. Aşsın zarar, borçlunun temerrüt tarihi ile fiili ödeme tarihi arasındaki doğmuş zararı ifade etmektedir².

\section{B. Hukuki Niteliği}

Aşkın zarar, müsbet zararın bir türüdür ${ }^{3}$. Müsbet zarar, alacaklının, borcun gereği gibi ifa edilememesinden dolayı borcun ifasındaki çıkarının gerçekleşmemesi yüzünden uğradığ zarardır ${ }^{4}$. Aşkın zarar sadece fiili zarardan ibaret değildir ${ }^{5}$, yoksun kalınan kâr da aşkın zararın konusunu oluşturabilir ${ }^{6}$. Aşkın zarar, temerrüt faizi ile karşılanamayan zarara ilişkin olduğundan asıl alacaktan bağımsız ${ }^{7}$ ve ek zarar niteliğindedir ${ }^{8}$. Sözleşmesel faizi aşan veya sözleşmesel faizle karşılanmayan zararlar aşkın zarar kapsamına girmez'. Bu zararın hukuki nedeni asıl alacağın temerrüde uğramasıdır ${ }^{10}$. Aşkın zarara dayalı talep hakkı, esas itibariyle bir alacak hakkıdır ${ }^{11}$. Aşkın zarar, kaynağı ne olursa olsun bütün para borçları için söz konusu olabilirir ${ }^{12}$.

\footnotetext{
${ }^{1}$ ERDOĞAN, İhsan: Borçlar Hukuku Genel Hükümler, Gazi Kitabevi, 4. Baskı, Ankara 2019, s.240, YAVUZ, Nihat: Borçlar Hukuku, Adalet Yayınevi, Ankara 2018, s.418, Y. 15. HD., E. 2018/3499, K. 2018/4739, T. 28.11.2018, (www.yargitay.gov.tr, ET: 01.02.2020), Y. 15. HD., E. 2014/6172, K. 2015/3745, T.29.06.2015 (www.yargitay.gov.tr, ET: 01.02.2020).

${ }^{2}$ KILIÇOĞLU, Ahmet M: Borçlar Hukuku Genel Hükümler, 23. Bası, Turhan Kitabevi, Ankara 2019, s.897.

3 AYRANCI, Hasan: Türk Borçlar Hukukunda Munzam Zarar, Yetkin Yayınları, Ankara 2006, s.116, TEKİNAY, Selâhhattin Sulhi/AKMAN, Servet/BURCUOĞLU, Hâluk/ALTOP, Atilla: Borçlar Hukuku Genel Hükümler, 7. Bask1, Filiz Kitabevi, İstanbul 1993, s.941.

${ }^{4}$ OĞUZMAN, M.Kemal/ÖZ, Turgut: Borçlar Hukuku Genel Hükümler, C.I, 14. Bası, Vedat Kitapçılık, İstanbul 2016, s.386.

5 Aksi yönde karar için bakınız. Y. HGK, E. 2007/11-668, K. 2007/798, T.31.10.2007. (www.yargitay.gov.tr, ET:02.01.2020). "Bu konuda kanıtlanması gereken, muayyen paranın gününde ödenmemesinden doğan zarardır. Diğer bir deyimle alacaklı davacı, fiilen uğradığı zararın ne olduğunu ve miktarını kanıtlamak durumundadır. Doğaldır ki bu zarar, paranın zamanında ödenmemesinden dolayı mahrum kalınan "muhtemel kâr" ya da "farz edilen gelir" değildir. Bu zarar, davacının öz varlığından, ekonomik ve sosyal faaliyetlerinden, toplum içerisindeki statüsünden, başına gelen olaylardan kaynaklanan, somut olgular nedeniyle uğramış olduğu fiili zarardır"

${ }^{6}$ KILIÇOĞLU, s.894. Yazara göre, aşkın zararın hukukî niteliği her somut olayın özelliğine göre belirlenmelidir. Müsbet zarar da olabilir menfi zararda olabilir.

${ }^{7}$ Y. 11. HD, E. 2018/1512, K. 2019/3201, T. 29.04 .2019 (www.yargitay.gov.tr, ET. 15.03.2020). "Munzam zarar borcunun hukuki sebebi, asıl alacağın temerrüde uğraması ile oluşan hukuka aykırılıktır. O nedenle, borçlunun munzam zararı tazmin yükümlülüğ̈̈ (TBK md. 122), asıl borç ve temerrüt faizi yükümlülüğünden tamamen farklı, temerrüt ile oluşmaya başlayan asıl borcun ifasına kadar zaman içinde artarak devam eden, asıl borçtan tamamen bağımsız yeni bir borçtur".

8 ALTAŞ, Hüseyin: "Munzam Zararda İspat Sorunu”, AÜHFD, 50(1), 2001, s.121, ÖÇAL, Akar: "Munzam Zarar”, Eskişehir İktisadi ve Ticari İlimler Akademesi Dergisi, Ocak 1967, 3(1), s.148, Y. 15. HD., E. 2014/6172, K. 2015/3745, T. 29.06.2015 (www.yargitay.gov.tr, ET: 01.02.2020).

${ }^{9}$ KILIÇOĞLU, s.897.

${ }^{10}$ Y. 11. HD., E. 2012/5385, K. 2013/5377, T. 19.03.2013, (www.yargitay.gov.tr, ET. 15.03.2020).

${ }^{11}$ Y.11. HD., E. 2012/5385,K. 2013/5377, T. 19.03.2013, (www.yargitay.gov.tr, ET. 15.03.2020).

12 ALTAŞ, s.121, AYRANCI, s.121, DUMAN, Özgür: "Enflasyon Karşısında Para Alacaklarının Korunması ve Mülkiyet, Uyuşmazlık Mahkemesi Dergisi”, 2018, (12), s.408-409, ERDOĞAN, s.240, KILIÇOĞLU, s.893.
} 


\section{C. Şartları}

1. Temerrüt faizini aşan bir zarar olmalıdır.

Para iktisadi açıdan bir değişim aracıdır. Mal ve hizmet bakımından da değer ölçüsüdür ${ }^{13}$. Para borcu bir "tutar borcudur" ${ }^{14}$ ve nominal değerdir ${ }^{15}$. Bu nedenle de borçlu, borçlandığı tutarı öderse, borcunu ifa etmiş olur. Borçlu borçlandığ 1 borcu ödeyeceği zaman, paranın değeri artsa da azalsa da borçlandığı tutarı ödeyecektir ${ }^{16}$. Para borcu, ancak temerrüt halinde değer borcuna dönüşür ${ }^{17}$. Paranın değer borcuna dönüşmesinin nedeni, paranın satın alma gücünün düşmesini engellemektir. Para, rakamla belirlenmiş bir değer olduğundan bir mal değildir ${ }^{18}$. Para borçlarında imkânsızlık söz konusu olamaz ${ }^{19}$.

Temerrüt faizi, para borçlarına ilişkin faiz türüdür ${ }^{20}$ ve para borcuna bağlı feri bir haktır ${ }^{21}$. Para borçlarında temerrüde düşen borçlu, temerrüt faizi ödemek zorundadır (TBK md 120, 3095 sayılı Kanuni Faiz ve Temerrüt Faizine İlişkin Kanun md 2). Temerrüt faizi kanundan doğmaktadır. Temerrüt faizi talep etmek için zararın varlığı gerekmez ${ }^{22}$.

Temerrüt faiz oranı tespit edilirken asıl amaç temerrüdü önlemektir. Temerrüt faiz oranı, borçluyu ifaya mecbur edecek nitelikte olmalıdır' ${ }^{23}$. Kanun koyucu, eBK' dan farklı olarak temerrüt faizinin üst sınırını belirlemiştir. Temerrüt faizinin sözleşme ile kararlaştırılması halinde temerrüt faizi oranı, yürürlükte olan mevzuat hükümlerine göre belirlenen temerrüt faizi oranının en fazla iki katı olabilir (TBK md 120/f.2).

Türk Borçlar Kanunu ve Türk Ticaret Kanunu'na göre faiz ödenmesi gereken hallerde faiz oranı sözleşme ile tespit edilmemişse 3095 sayılı Kanun hükümleri uygulanır. Faiz oranı belirlenirken borçlunun zayıf durumda olma ihtimâli de dikkate alınarak menfaatlerinin korunması gerekir. Bu nedenle Türk Borçlar Kanunu'nda sözleşmesel faiz oranı için de temerrüt faizi için de sınırlama getirilmiştir. Sözleşmesel faiz oranı, yürürlükte olan mevzuat hükümlerinde düzenlenen faiz oranının yüzde ellisinden fazla olamaz (TBK md 88/f.2). Taraflar sözleşmede sözleşmesel faiz oranını belirlemiş fakat temerrüt faiz oranını belirlememiş olabilirler. $\mathrm{Bu}$ durumda, kararlaştırılan faiz oranı yürürlükteki temerrüt faizinden yüksekse temerrüt halinde sözleşmesel faiz uygulanır. Aksi halde 3095 sayılı Kanun'da düzenlenen temerrüt faiz oranı uygulanır (TBK md 120/f.son).

Tarafların temerrüt faizi kararlaştırmaları aşkın zararı talep etme haklarını kullanamayacakları anlamına gelmez ${ }^{24}$. Taraflar temerrüt faizini belirlerken, mevzuattaki faiz oranını iki katına çıkarmışlarsa bu durumda aşkın zararın talep edilip edilemeyeceği hususu üzerinde de durulması gerekir. Türk Borçlar Kanunu'nda yürürlükten kalkan eBK'dan ${ }^{25}$ farklı olarak temerrüt faizi için belirlenecek üst sınır düzenlenmiştir ve ilgili hüküm emredici niteliktedir (TBK md 120/f.2). İlgili hükmün "ticari işlerde" de uygulanıp uygulanmayacağ 1 hususu tartışmalıdır. Türk Ticaret Kanunu gereğince, "ticari işlerde faiz oranı serbestçe belirlenir"

\footnotetext{
${ }^{13}$ BARLAS, Nami: Para Borçlarının İfasında Borçlunun Temerrüdü ve Bu Temerrüt Açısından Düzenlenen Sonuçlar, Kazancı Kitap Ticaret A.Ş, İstanbul 1992, s.5, NOMER, Haluk: "Para Borcu Kavramı ve Para Borçlarının BK md 115/I Anlamında Aynı Cinsten Kabul Edilip Birbiriyle Takas Edilebilirliği Problemi”, İ̈HHFM, LVII(1-2), 1999, s.242.

14 BARLAS, s.13, SEROZAN, Rona: "Para Alım Gücünün Düşmesine Bağlı Kayıpların Karşılanmasında Eşitsizlikler", İ̈̈HFM, C.20, 1996, s.42.

${ }^{15}$ ZEYTINOĞLU, Erol: "Para Borçlarında Temerrüt Hallerinde Munzam Zarar”, İstanbul Ticaret Üniversitesi Sosyal Bilimler Dergisi, (8), Güz 2005/2, s.254.

16 TEKİNAY/AKMAN/BURCUOĞLU/ALTOP, s.782. Yazarların, itibarî değer teorisi olarak nitelendirdikleri teori, kanaatimizce paranın tutar borcu olduğunu açıklamaktadır.

17 SEROZAN, s.242.

${ }^{18}$ NOMER, s.243.

${ }^{19}$ SEROZAN, s.41.

${ }^{20}$ EREN, Fikret: Borçlar Hukuku Genel Hükümler, 19. Bask1, Yetkin Yayınları, Ankara 2015, s.1099, HELVACI, Mehmet: Borçlar ve Ticaret Kanunu Bakımından Para Borçlarında Faiz Kavramı, Beta Yayınevi, İstanbul 2000, s.44, TEKINAY/AKMAN/BURCUOĞLU/ALTOP, s.929-930.

${ }^{21}$ BUZ, Vedat: "Karşılaştırmalı Hukukta Munzam Zararın İspatı”, Yargıtay Dergisi, (3), 1998, s.369, HELVACI, s.30.

22 BARLAS, s.191, DUMAN, s.410, ERDOĞAN, s.239, KAYA, Aslan: “Adi ve Ticari İşlerde Faiz”, İ̈HHM, 54(14), 1994, s.357, KILIÇOĞLU, s.894.

${ }^{23}$ BUZ, s.393.

24 ÖÇAL, s. 156.

25 TEKINAY/AKMAN/BURCUOĞLU/ALTOP, s.944. Yazarlar, eBK döneminde şu görüşü dile getirmişlerdir: “Alacaklı, borçlunun temerrüdü nedeniyle parasını bu şekilde değerlendiremediğine göre, onun ek (munzam) zararının vadeli banka hesabına uygulanan faiz oranına eşit olduğu bir karine olarak kabul edilmelidir”.
} 
(TTK md 8/1). Yasal düzenlemede ifade edilen "serbestinin sınırının" nasıl belirleneceği konusunda kanun koyucu, doğrudan bir oran öngörmemiştir. Sadece, "kanuni, anapara ile temerrüt faizi" hakkında, ilgili mevzuat hükümlerinin uygulanacağ d düzenlenmiştir.(TTK md 9/1). "İlgi mevzuat hükümlerinden", ne anlaşılması gerektiği tartışmalıdır. Bir görüşe göre ${ }^{26}$, TBK' da faize ilişkin getirilen emredici düzenlemede borçlunun niteliği bakımından ayrım yoktur. Ayrıca, ticari iş sayılan sözleşmelerden doğan borçların tarafı tacir olmayabilir. $\mathrm{Bu}$ nedenle de TBK' da faize ilişkin getirilen emredici düzenlemeler ticari işler için belirlenen faiz oranları için de geçerlidir. Diğer görüş̧ ${ }^{27}$ ise, TTK'da düzenlenen hükümlerin TBK'ya göre özel hüküm niteliğinde olduğunu ve bu nedenle de "ticari işlerde faize" ilişkin TBK'nın hükümlerinin uygulanamayacağını ifade etmektedir. Kanaatimizce de, TTK' da faize ilişkin getirilen hükümler özel hüküm niteliğinde olduğundan TBK'nın hükümlerinin "ticari işlerde" uygulanabilmesi mümkün değildir.

Alacaklı ve borçlu temerrüt faizine ilişkin özel oran tespit etmişlerse, aşkın zararın varlığından bahsedilebilmesi için kararlaştırılan faiz oranını aşan zararın varlığı gerekir. Bir diğer ifade ile temerrüt faizine ilişkin özel oran kararlaştırılması aşkın zarar iddiasının ileri sürülmesine engel olmaz ${ }^{28}$.

\section{Borçlunun Kusurlu Olması Gerekir}

Temerrüde düşen borçlu, bu sonucu bilerek ve isteyerek meydana getirmişse borçlunun kastından bahsediliir ${ }^{29}$. Eğer borçlu, gerekli özeni göstermeyerek temerrüde neden olmuşsa borçlunun ihmâlinden bahsedilir. İhmâl, ağır ve hafif olmak üzere ikiye ayrılır. Ağır ihmâlde, makul bir insanın davranışı ölçü alınır ve makul bir insanın alması gereken en basit önlemin alınmaması söz konusu olur ${ }^{30}$. Hafif ihmâlde ise, dikkat ve özen gösteren insan davranışı ölçü alınır ve hafif ihmal ölçü alınan kişinin göstermesi gereken davranışın gösterilmemesi şeklinde ortaya çıkar ${ }^{31}$.

Temerrüde düşen borçlu karine gereğince kusurlu sayılır (TBK md 118). Bu nedenle borçlu kusursuz ise kusursuz olduğunu ispat etmesi gerekir aksi hâlde kusurlu kabul edilir. Temerrüde düşen borçlu kusursuz olduğunu ispat ederse aşkın zararı ödemekten kurtulur. (TBK md 122/f.1). Hafif düzeyde bile kusurun varlığı hâlinde borçlu kusursuz olduğunu ispat edemez.

Yargıtay'a göre ${ }^{32}$ borçlu, alacaklının bir zarara uğramadığını ya da borcunu zamanında ifa etmiş olsa dahi alacaklının değeri düşmeyecek bir yatırım yapmayacağını ispat ederek sorumluluktan kurtulabilir.

\footnotetext{
${ }^{26}$ AYDOĞDU, Murat: “6098 sayılı Türk Borçlar Kanununda Faiz ile İlgili Düzenlemeler”, DEÜHF, 12(1), 2020, s.95.

${ }^{27}$ ATAMER, Yeşim M./SANLI, Kerem Cem: "Borçlar Kanunu'ndaki Faiz Serbestisini Sınırlayan Hükümlerin Uygulama Alanı: Hukuk, Ekonomi ve Davranışsal Ekonomi Perspektifinden Bir İnceleme”, YD, 42(3), Temmuz 2016, s.435-436, OĞUZMAN/ÖZ, s.494, YAĞCI, Kürşad: “Anapara Faizi ve Temerrüt Faizine Üst Sınır Getiren TBK M.88 ve TBK M.120 Hükümlerinin Ticari Faizler (TTK M.8 ve TTK.M.9 Bakımından Uygulanabilirliği”, IÜHFM, 71(2), 2013, s.432, YHGK, E.2017/1650, K.2019/507, T.02.05.2019 (ET:08.07.2020). “Anılan hükümde sözü edilen ilgili mevzuatın 3095 sayılı Kanun hükümleri olduğunun, akdi faiz oranı yönünden bir sınırlama getirmediğinin ve 6102 sayılı TTK'nın 8. ve 9. maddelerinin ticari ișler bakımından özel hüküm niteliğinde olup ticari ișlerde bu hükümlerin uygulanması gerektiğinin, başka bir anlatımla 6098 sayılı TBK'nın 88. ve 120. maddeleri hükümlerinin ticari işlerde uygulanamayacağının kabulü gerekir”.

${ }^{28}$ BARLAS, s.191, KILIÇOĞLU, s.897.

${ }^{29}$ EREN, s.1061, OĞUZMAN/ÖZ, s.405, TEKİNAY/AKMAN/BURCUOĞLU/ALTOP, s.874.

${ }^{30}$ EREN, s.580.

${ }^{31}$ EREN, s.580.

32 Y. 15. HD., E. 2013/3885, K. 2014/4268, T. 19.06.2014. (www.yargitay.gov.tr, ET: 01.04.2020). "Bu görüş doğrultusundaki uygulamaları gösterir örnek kararlar olarak; Y. HGK. 19.10.1996 gün, 96/5-144 Esas ve 1996/503 sayılı kararı; 17.12.1999 gün, 99/19-73 Esas ve 99/106 Karar sayılı ilâmı, 08.11.2001 tarih, 2000/5-1611 Esas ve 2000/1636 Karar sayılı ilâmı; Yargitay 5. Hukuk Dairesi'nin 08.02.2000 gün, 1999/19708 Esas ve 2000/1451 say1l Kararı, 15. Hukuk Dairesi'nin 26.11.1998 gün, 1998/4379 Esas ve 98/4426 sayılı ilâmı ve 27.01.1995 gün, 94/4985 Esas ve 1995/363 sayılı Kararı, 19. Hukuk Dairesi'nin 02.10.1997 gün, 97/4815 Esas ve 97/7979 sayılı kararı, gösterilebilir".
} 


\section{Nedensellik Bağ1}

Aşkın zarar ile borçlunun temerrüdü arasında nedensellik bağının olması gerekir. Uygun nedensellik bağının varlığını alacaklı ispat etmelidir ${ }^{33}$. Nedensellik bağının varlığ soyut veya somut ispat yöntemine göre farkl111k göstermektedir ${ }^{34}$.

\section{Alacaklının Talep Etmesi Gerekir.}

Temerrüt faizinde olduğu gibi aşkın zarar için de alacaklının talebi gerekir. Asıl borç, ifa ya da başka bir sebeple sona erdiği takdirde asıl alacağa bağlı faiz de sona erer (TBK md 131/f.1). Asıl alacağa bağlı olarak işlemiş faizi isteme hakkı sözleşmeyle veya ifa anına kadar yapılacak bir bildirimle saklı tutulmuş ise ya da durum ve koşullardan saklı tutulduğu anlaşılıyorsa, işlemiş faiz talep edilebilir (TBK md 131/f.2). Aşkın zararın talep edilebilmesi için asıl alacağın faizi ile birlikte tahsili amacıyla açılan icra takibinde veya davada saklı tutulmasına gerek yoktur ${ }^{35}$. Çünkü, aşkın zarar, temerrüt faizi ile karşılanamayan zarara ilişkin ve asıl alacaktan bağımsız ${ }^{36}$ olup ek zarar niteliğindedir ${ }^{37}$.

\section{AŞKIN ZARARI BELIRLEME YÖNTEMLERİ}

Aşkın zararın varlığını ispat külfeti, aşkın zararın varlığını iddia edene düşer ${ }^{38}$. Aşkın zararı hangi yönteme göre ispat edeceğini, zarar gören seçecektir. Kanun koyucu hangi yöntemin uygulanacağına ilişkin bir düzenlenmeye yer vermemiştir. Bu nedenle de aşkın zararın ispatında hangi yöntemin uygulanabileceği yargı kararlarıyla şekillenmektedir. Zarar miktarı hesaplandıktan sonra varsa indirim sebepleri dikkate alındıktan sonra tazminata hükmedilir.

Zarar miktarının hesaplanabilmesi için iki yöntem vardır. Birincisi somut yöntem, ikincisi ise soyut yöntemdir ${ }^{39}$.

\section{A. Somut Yöntem}

Somut yöntemin uygulanması durumunda, zararın varlığını iddia eden, somut vakıalar ile zararının varlığını ispat etmelidir. Ayrıca temerrüt ile zarar arasındaki nedensellik bağını da ispat etmek zorundadir.

$\mathrm{Bu}$ yöntemde fiili karinelerden yola çıkarak zararı ispat etmek mümkün değildir ${ }^{40}$. Öğretide bazı yazarlar, aşkın zararın somut olarak ispat edilmesi gerektiğini savunmaktadırlar ${ }^{41}$. Diğer yazarlara göre ${ }^{42}$, enflasyon gibi ekonomik olumsuzluklar sebebiyle para değerindeki düşüş oranının temerrüt faiz oranından yüksek olması başlı başına aşkın zarar sebebidir.

AYRANCI' ya göre ${ }^{43}$, somut yöntem daha çok fiili zararlar için söz konusu olabilir.

\footnotetext{
${ }^{33}$ ALTAŞ, s.123, BARLAS, s.192. Y. 21. HD., E. 2016/6419, K. 2017/6419, T. 21.11.2017, (www.yargitay.gov.tr, ET: 01.04.2020). "Bu ek (munzam) zarar alacaklısı öncelikle temerrüde uğrayan asıl alacağın varlığını, bu alacağının geç ifa edilmesinden dolayı faizle karşılanamayan zararını ve miktarını zarar ile borçlu temerrüdü arasındaki uygun illiyet bağını ispat etmek durumundadır"

${ }^{34}$ Bakınız. "II, A ve B".

${ }^{35}$ ERDOĞAN, s.240, Y. 15. HD., E.2018/3499, K. 2018/4739, T. 28.11.2018. (www.yargitay.gov.tr, ET: 01.04.2020). "Asıl alacağın faizi ile birlikte tahsiline yönelik icra takibinde veya davada munzam zarar hakkının saklı tutulduğunu gösteren bir ihtirazî kayıt dermeyanına da gerek bulunmamaktadır".

${ }^{36}$ Y. 11. HD, E. 2018/1512, K. 2019/3201, T. 29.04 .2019 (www.yargitay.gov.tr, ET. 15.03.2020). "Munzam zarar borcunun hukuki sebebi, asıl alacağın temerrüde uğraması ile oluşan hukuka aykırılıktır. O nedenle, borçlunun munzam zararı tazmin yükümlülüğü (TBK md. 122), asıl borç ve temerrüt faizi yükümlülüğünden tamamen farklı, temerrüt ile oluşmaya başlayan asıl borcun ifasına kadar zaman içinde artarak devam eden, asıl borçtan tamamen bağımsız yeni bir borçtur".

${ }^{37}$ ALTAŞ, Hüseyin: "Munzam Zararda İspat Sorunu”, AÜHFD, 50(1), 2001, s.121, ÖÇAL, Akar: "Munzam Zarar”, Eskişehir İktisadi ve Ticari İlimler Akademesi Dergisi, Ocak 1967, 3(1), s.148, Y. 15. HD., E. 2014/6172, K. 2015/3745, T. 29.06 .2015 (www.yargitay.gov.tr, ET: 01.02.2020).

${ }^{38}$ EREN, s.1108, OĞUZMAN/ÖZ, s.500, YAVUZ, s.461.

${ }^{39}$ SEROZAN, s.45. Yazar, iki yöntemin ayrımını şu şekilde yapmaktadır: "Küçükler, paralarını genelde elde tuttukları veya harcadıkları için somut zararlarını inandırıcı kılabilme yolunda terlerken, büyükler tipikleştirilmiş soyut ve nesnel zarar hesabının kolaylıklarında serinler"

${ }^{40}$ ALTAŞ, s.124.

${ }^{41}$ ALTAŞ, s.123, KAYA, s.349, ZEYTINOĞLU, s.262.

42 ANTALYA, Gökhan: Borçlar Hukuku Genel Hükümler, V(1,3), Seçkin Yayınevi, 2.Bask1, Ankara 2019, s.530, BARLAS, s.210, HELVACI, s.88, KILIÇOĞLU, s.911, TEKİNAY/AKMAN/BURCUOĞLU/ALTOP, s.943-944, YAVUZ, s.461.

${ }^{43}$ AYRANCI, s.144. 
Somut zarar çeşitli şekillerde karşımıza çıkar. Borçlunun temerrüdü nedeniyle alacaklının yüksek oranlı faiz ile kredi kullanması, ödediği kredi dosya masrafları, alacaklının temerrüt nedeniyle üçüncü kişilere ödemek zorunda kaldığı cezai şart ve sahibi olduğu paraya çevrilecek malvarlığı değerlerini ucuza satmak zorunda kalması, bu zarar türüne örnek olarak gösterilebilir.

Somut yöntemin uygulanmasını bir örnek üzerinden açıklayalım. Tacir A, Tacir B’ye 100.000 TL borç vermiştir. Borcun vadesi 02.01.2013 olmasına rağmen B, A'ya olan borcunu ödememiştir. A, B'ye karşı dava açmış ve açtığı dava lehine sonuçlanmıştır. A, alacağını cebri icra ile 02.01.2020 tarihinde tahsil edebilmiştir. Taraflar arasında temerrüt faizi kararlaştırılmadığı için ve 3095 sayılı Kanun gereğince ticari avans faizi uygulanacaktır. A, B'nin borcunu zamanında ifa etmediğini ve bu nedenle de kredi kullanmak zorunda kaldığını belirtmiştir. A'nın iddiasına göre, bankaya ödemek zorunda kaldığı sözleşmesel faiz ve kredi dosya masrafları temerrüt faizini aşmaktadır. Bu nedenle de B'ye karşı aşkın zararın tahsili için dava açtı̆̆ını ve açılan davada B'nin, kusursuz olduğunu ispat etmediğini kabul edelim. Bu davada, A'nın bankadan kredi kullanmasından kaynaklanan faiz ve masrafların varlığı dışında B'nin temerrüdü ile A'nın davaya konu maliyetlere katlanması arasında nedensellik bağının olduğunu ispat etmesi gerekir. Bu nedenle de, Bay A'nın, işletmesinin faaliyet alanı, B ile arasındaki borç ilişkisine konu olan borcun miktarı, A'nın sermaye gücü, Bay A'nın B'den olan alacağı dışında zamanında tahsil edemediği alacaklarının olup olmadı̆̆ kredisinin zorunlu olup olmadığı, kredi maliyetlerinin teamüllere uygun olup olmadığı gibi verilerin de ayrı ayrı incelenmesi gerekir. A'nın, aşkın zararının varlığından bahsedebilmek için mevcut veriler ile zarar arasında uygun nedensellik bağının kurulması gerekir. Hayatın olağan akışı gereğince, alacağını zamanında alamayan alacaklının para alacağını geç almasından kaynaklanan zarar ile borçlunun temerrüdü arasında nedensellik bağını ispat etmesi güçtür. Çünkü nedensellik bağı değerlendirilirken birçok faktörün değerlendirilmesi gerekmektedir.

Yargıtay'ın kararına konu olan bir olayda ${ }^{44}$ davalı banka, davacı kuyumcunun pos cihazı ile yaptığı satışa haksız bloke koymuştur. Davacının davalı aleyhine açtığı dava, davacı lehine sonuçlanmıştır. Davacı alacağını tahsil etmesine rağmen altın fiyatlarındaki artıştan dolayı temerrüt faizini aşan zararı olduğu gerekçesiyle aşkın zararın tahsili amacıyla dava açmıştır. Yargıtay, kuyumculuk işi yapan davacının, alacağını davalı bankadan geç almasından dolayı açılan aşkın zarara ilişkin davanın kabulüne karar verilmesi gerektiğini belirtmiştir. Gerekçede davacı kuyumcunun, alacağını zamanında alması halinde hayatın olağan akışı ve mesleği gereğince altın alacağının kabulü gerektiği vurgulanmıştır.

Yargıtay kararlarına bakıldığında ispat ölçüsü olarak genellikle somut yöntemin uygulanması gerektiği görülür. Yargıtay’a göre ${ }^{45}$, enflasyon ve devalüasyon artışlarının varlığı, aşkın zararın ispatlandığı anlamına gelmemektedir. Alacaklının kanıtlaması gereken husus, kendisinin şahsen ve somut olarak geç ödemeden dolayı uğradığı zarardır.

\footnotetext{
44 Y. 11. HD., E. 2014/731 ,K. 2014/19357, T. 09.12.2014.(www. yargitay.gov.tr, E.T. 13.04.2020). Y.19.HD.,E. 2017/5217, K. 2019/5474, T. 09.12.2019. "Davacının davalılardan tahsil ettiği anapara ve faiz toplamının, davacının sattığı malı yeniden tedarik etmesi için ödemesi gereken bedelle kıyaslayıp arada davacı aleyhine bir fark varsa davacının munzam zararının bu olduğunun kabulü ile sonucuna göre karar vermekten ibarettir. Ancak hükme esas alınan bilirkişi raporu bu ilkelere uygun düzenlenmemiştir. Eksik soruşturmayla hüküm kurulamaz, bu nedenle hükmün bozulması gerekmiştir".

${ }^{45}$ Y. 19. HD., E. 2014/6154, K. 2015/3225, T. 09.03.2015. (www.yargitay.gov.tr, E.T 01.04.2020). Y. 11. HD., E. 2014/13418, K. 2014/19400, T. 10.12.2014. (www.yargitay.gov.tr, E.T 01.04.2020). "Her ne kadar davac1, döviz faizini aşan bir zararı olduğu iddiasıyla davayı açmış ise de, zararın ne şekilde oluştuğunu somut olarak ispat etmiş değildir. Bu durumda, HGK'nun 2001-19/1086 E, 2002/371 K. sayılı kararı da göz önünde bulundurulduğunda davanın bu sebeple reddi gerekirken yazılı gerekçe ile reddi isabetli değil ise de, sonucu itibariyle doğru olan kararın HUMK 437/7. maddesi gereğince açıklanan bu gerekçe ile onanmasına karar vermek gerekmiştir".

Y. 5. HD., E. 2014/10900, K. 2014/26089, T. 13.11.2014. "Kamulaştırma Kanunu uyarınca belirlenen bedele faiz uygulanması şeklinde bir çözüm getirildiğinden, artık munzam zarar talebinin değerlendirilmesi söz konusu olamaz. Aksi düşünülse bile munzam zarar hükmedilebilmesi için davacı alacaklının zararının faizle karşılanamadığını, bunun üstünde zararının oluştuğunu, maddi vakıalarla ve belgelerle kanıtlanması gerekir".

Y. 15. HD., E. 2011/7614, K. 2012/1895, T. 26.03.2012, (www.yargitay.gov.tr, E.T 01.04.2020). "Yüksek enflasyon dolar kurundaki artış serbest piyasadaki faiz oranlarının yüksek oluşu davacıyı kanıt yükünden kurtaramaz. Zira davacı para alacağını zamanında alması halinde ne şekilde kullanacağını kanıtlayamamıştır”. Y. 13. HD., E. 2016/10665, K. 2019/6982, T. 30/05/2019. (www.yargitay.gov.tr, E.T 01.04.2020). "Ülkede yaşanan ekonomik kriz nedeniyle paranın döviz karşısında hızlı değer kaybı, yüksek enflasyon gibi genel afaki ve doğrudan davacının zararını ifade etmeyen umumi ekonomik konjonktürel olgular BK'nın 105. (T.B.K. 122.) maddesinde sözü edilen munzam zararın varlığını göstermez".
} 


\section{B. Soyut Yöntem}

Soyut yöntem ile alacaklıya ispat kolaylığı sağlanmaktadır, çünkü zarar soyut olarak hesaplanmaktadır ${ }^{46}$. AYRANCI' ya göre ${ }^{47}$ soyut zararın hesaplanması genellikle yoksun kalınan kârın hesaplanmasında kullanabilecek bir yöntemdir. Bu yöntemde belli ekonomik göstergeler dikkate alınarak değerlendirme yapılır. Alacaklı bu yöntemde uğradığı zararı somut vakıalarla ispat etmek zorunda değildir. Temerrüt faizi ile karşılanmayan zararın varlığını başta enflasyon, devalüasyon, altın fiyatlarındaki artış, tüketici fiyat endeksi, üretici fiyat endeksi ve asgari ücret artış oranlarındaki artıştan yola çıkarak ispat edebilir.

YHGK' nın 31.10.2007 tarihli ve 2007/11-688 E. ${ }^{48}$ say1lı kararında, soyut ispat yönteminin neden uygulanamayacağı aşağıdaki gerekçelerle açıklanmıştır.

-Kanun koyucu, ülkemizin içinde bulunduğu ekonomik durumu dikkate alarak faizi düzenlemiştir.

-Ülkenin içinde bulunduğu enflasyon, yüksek faiz gibi ekonomik olumsuzluklar, aşkın zararın ispat vasıtaları olarak kabul edilemez. Ekonomik olumsuzluklar, gerçek zarar olarak gösterilemez.

-Ekonomik verileri değerlendirip sonuçlarına ilişsin faize dair yasal düzenleme yapma yetkisi Anayasa gereğince, yasama organına aittir.

-Aşkın zararın ispatı, maruf ve meşhur olgulara göre değil, somut vakıalara göre yapılır.

ALTAŞ' a göre ${ }^{49}$, alacaklının somut zararına bakılmaksızın enflasyon oranında bir zarara uğradığını kabul etmek, kanun koyucunun yerine geçerek yasal temerrüt faiz oranını enflasyon oranına çıkarmak anlamına gelir.

YHGK, 13.06.2012 tarih ve 2011/18-730 E. ${ }^{50}$ sayılı kararında kamulaştırma bedelinin geç ödenmesinden doğan aşkın zarar iddiasının soyut yöntemlere dayanılarak ispat edileceğine hükmetmiştir. Karara göre, alacaklı zararını ispatlarken yüksek enflasyon gibi bilinen vakıalara dayanabilir ve bu şekilde üzerine düşen ispat külfetini yerine getirilebilir. Somut olay itibariyle, davacılar taşınmazlarının kamulaştırma bedelini uzun süre alamamışlardır. Bu nedenle de tahsil edilmeyen bu bedelin dava tarihindeki satın alma gücü dikkate alındığında, davacıların zararlarını kanıtlamış olduklarının kabulü gerekir.

Aşkın zararın ispatında soyut yöntem, somut yönteme göre daha elverişlidir. İspat sorununun bu yönteme göre çözülmesi varılan sonucun mutlaka adalete uygun olduğunu göstermez. BUZ' a göre bu yöntem, "hukuki çaresizlik içerisinde tutunacak son bir dal, çalınacak son kapı olarak değerlendirilmelidir". ANTALYA ise ${ }^{51}$, bu yöntemin farazi karaktere sahip olduğu için sınırlandırılması gerektiğini savunmaktadır.

\section{ANAYASA MAHKEMESI KARARINA GÖRE AŞKIN ZARARIN İSPATI}

Kamu kurumuna iş yapan ve para alacağını zamanında alamadığ 1 için dava açan ve açtığ dava kısmen lehine sonuçlanan inşaat şirketi, temerrüt faizi ile karşılanmayan zararı olduğu gerekçesiyle aşkın zararın tahsili için dava açmıştır. Somut olayda davacıya 62.969,69 TL asıl alacağı yanında 348.027,70 TL tutarında faiz ödemesi yapılmıştır.

Başvuru sahibinin, aşkın zarara ilişkin davası reddedilmiştir ve ret kararına karşı başvurulan kanun yollarından sonuç alınmamış ve karar kesinleşmiştir. Bu nedenle de Anayasa Mahkemesi'ne bireysel başvuruda bulunmuştur.

Anayasa Mahkemesi'nin kararında vurgulanan hususları şu şekilde sıralayabiliriz:

- Para, ekonomik bir değişim vasıtasıdır ve sahibine çeşitli yararlar sağlar. Paradan mahrum kalınması hâlinde mahrum kalınan dönemde, para enflasyon ve devalüasyondan dolayı değer kaybeder.

\footnotetext{
${ }^{46}$ BUZ, s.404.

${ }^{47}$ AYRANCI, s.144.

${ }^{48}$ Y. HGK, E. 2007/11-668, K. 2007/798, T. 31.10.2007. (www.yargitay.gov.tr, ET:02.01.2020).

${ }^{49}$ ALTAŞ, s.128.

${ }^{50}$ YHGK, E. 2011/18-730 E, K. 2012/373, T. 13.06.2012. (www.yargitay.gov.tr, ET:18.01.2020).

${ }^{51}$ ANTALYA, s.530.
} 
- Para alacağını geç almak alacaklının zararına borçlunun yararına sonuçlar doğurmaktadır. Paranın tahsili için yargı yoluna başvurulduğunda, yargıdaki iş yükü nedeniyle davalar uzamakta bundan dolayı yargıya duyulan güven azalmaktadır. Bu durum kendiliğinden hak alma düşüncesini yaygınlaştırarak kamu düzenini bozmakta, kişi ve toplum güvenliği sarsilmaktadir.

- Yargılamada geçen süre nedeniyle paranın enflasyon sonucu değer kaybetmesi mülkiyet hakkının ihlâlidir. Bu değerlendirmeye ilişkin bir başka ilke kararına atıf yapılmıştır. (Abdulhalim Bozboğa, B. No:2013/6880, 23/03/2016)

- Alacaklar da mülkiyet hakkı kapsamındadır. Devlet tarafından alacakların geç ödenmesi hâlinde enflasyon oranları altında olmayan bir faiz ödenmesi, gerek bireyin hakları gerekse de kamu düzeni bakımından önem taşır. Bu nedenle de kişilerin mülkiyet hakkı kapsamında değerlendirilen alacaklarının, kamu kurumlarınca makul olmayan bir sebeple geç ödenmesi yüzünden değer kaybına uğratılması mülkiyet hakkının ihlaline yol açar.

- Başvurucunun alacağı, enflasyon karşısında önemli bir değer kaybetmiştir. Bu tespite rağmen başvurucunun, ayrıca zarara uğradığını ispat etmesi şeklindeki katı yorum nedeniyle, kamu yararı ile başvurucunun mülkiyet hakkının korunması arasında kurulması gereken adil denge, başvurucu aleyhine bozulmuştur.

- Karar oy çokluğu ile verilmiştir. Karşı oyda gerekçe olarak, söz konusu davanın bir alacak davası değil tazminat davası olduğu, başvurucunun tazminat talep etmeyeceği yönünde sözleşmede hüküm olduğu dikkate alındığında mülkiyet hakkının ihlâl edildiği yönündeki iddianın yersiz olduğu belirtilmiştir. Başvurucunun zarara uğradığını ayrıca ispat etmesi gerektiği belirtilmiştir.

\section{YARGITAY HUKUK DAİRELERININ ANAYASA MAHKEMESİ KARARI SONRASI AȘKIN ZARARIN İSPATINA İLISSTIN DEĞERLENDİRMELERİ}

Yargitay 13. Hukuk Dairesi ${ }^{52}$, Yargitay 5. Hukuk Dairesi ${ }^{53}$, Yargitay 19. Hukuk Dairesi ${ }^{54}$ kararları incelendiğinde, aşkın zararın ispatında somut yönteminin uygulanması gerektiğinin belirtildiği görülmektedir. Kararlarda, enflasyon ve devalüasyon gibi ekonomik verilerin soyut veriler niteliğinde olduğu ve aşkın zararın varlığının somut olarak ispat edilmesi gerektiği belirtilmektedir. Yargitay 4. Hukuk Dairesi ${ }^{55}$, Yargitay 11. Hukuk Dairesi ${ }^{56}$, Yargitay 17. Hukuk

${ }^{52}$ Y. 13. HD., E. 2016/10665, K. 2019/6982, T. 30.05.2019. (www.yargitay.gov.tr, E.T 01.04.2020). “Ülkede yaşanan ekonomik kriz nedeniyle paranın döviz karşısında hızlı değer kaybı, yüksek enflasyon gibi genel afaki ve doğrudan davacının zararını ifade etmeyen umumi ekonomik konjonktürel olgular BK'nın 105. (TBK. 122.) maddesinde sözü edilen munzam zararın varlığını göstermez".

${ }^{53}$ Y. 5. HD., E. 2017/17121, K. 2019/604 ,T. 21/01/2019. (www.yargitay.gov.tr, E.T 01.04.2020).” Kanun koyucu para borcunun geç ödenmesi ya da ödenmemesi halinde bir zararın mevcut olduğunu kural olarak benimsemiştir. Diğer bir deyişle temerrüt faizi miktarınca alacaklının zarara uğradığı yasal bir karine olarak kabul edilmiştir. Bunun dışında davacının herhangi karineden istifade etme olanağı yasal olarak mevcut değildir.

Davacı; para alacağını zamanında tahsil etmesi halinde ne şekilde kullanacağını, paranın zamanında verilmemesi nedeniyle faiz dışında ne gibi maddi zararlarının oluştuğunu; somut delilerle ispat edemediğinden munzam zarar istemine ilişkin davanın reddi yerine yazılı şekilde davanın kabulüne karar verilmesi.."

${ }^{54}$ Y. 19. HD., E. 2018/1690, K. 2019/2185, T. 02.04.2019, (www.yargitay.gov.tr, E.T. 01.04.2020). "Mücerret enflasyon, döviz kurlarındaki yükselme veya bankaların uyguladığı faiz oranlarındaki artışlar tek başına munzam zararın gerçekleştiği veya kanıtlandığı anlamına gelmez. Alacaklının kanıtlaması gereken husus yukarıda açıklanan genel olgular değil, kendisinin şahsen ve somut olarak geç ödemeden dolayı zarar gördüğ̈ keyfiyetidir. Mahkemece, açıklanan hususlar gözetilmeden eksik inceleme ile düzenlenen bilirkişi raporuna göre karar verilmesi doğru olmamiştır".

55 Y. 4. HD., E. 2017/154, K. 2019/5415, T. 20/11/2019. (www.yargitay.gov.tr, E.T 01.04.2020). "Bu nedenle denkleştirici adalet ilkesi gereğince güncelleme yapılırken, satış bedeli olarak verilen paranın dava tarihi itibariyle enflasyon, tüketici eşya fiyat endeksi, altın ve döviz kurlarındaki artışlar, memur maaş ve işçi ücretlerindeki artışlar gibi çeşitli ekonomik etkenlerin ortalamaları alınmak sureti ile uygulama sonucu ulaşacağı alım gücü, belirtilen ilke ve esaslar dikkate alınarak bu konu da uzman bilirkişi veya kurulundan Yargıtay denetimine elverişli rapor alınarak belirlenmeli ve bu yolla belirlenecek miktara hükmedilmelidir." şeklinde belirlemelere yer verilmiştir"

${ }^{56}$ Y. 11. HD., E. 2018/193, K. 2019/4929, T. 27.06.2019. (www.yargitay.gov.tr, ET: 01.04.2020). " Munzam zararın tespit edilebilmesi için dava konusu senedin vade tarihinden, icra takibine konu alacağın temlik edildiği 07.06.2012 tarihine kadar geçen süre içerisinde her yıl itibarı ile gerçekleşen yıllık enflasyon artış oranı, bu oranın eşya fiyatlarına yansıma durumu, mevduat ve Devlet tahvillerine verilen faiz oranları, Türk Lirası karşısında döviz kurlarına ilişkin değişiklik listeleri davacıdan istenmek, gerektiğinde bunları ilgili resmi kurum veya kuruluşlardan araştırmak, bu sahada uzman bilirkişi görüşünden de yararlanılmak suretiyle bu süre içerisindeki para değerinin düşmesi, alım gücü azalması nedeniyle alacaklının maruz kaldığı zarar miktarının yukarıda değinilen unsurların toplanıp, ortalamaları bulunarak belirlenmek ve istenilen alacağın temel hukuki yapısı nedeniyle bir tazminat alacağı niteliğinde olduğundan ve bu zararın oluşmasında ülkenin içinde bulunduğu ekonomik ve sosyal ortamın da etkili bulunduğu ve bundan ülkede yaşamını sürdüren gerçek veya tüzel kişilerin etkilenmemesinin kaçınılamaz olduğu ve nihayet her somut olayın 
Dairesi ${ }^{57}$ kararları incelendiğinde aşkın zararın ispatında soyut yöntemin uygulanması gerektiği yönünde hüküm tesis edildiği görülmektedir. Kararlarda, enflasyon, devalüasyon, tüketici eşya fiyat endeksi, altın kurlarındaki artışlar, memur maaş ve işçi ücretlerindeki artışlar gibi çeşitli ekonomik etkenlerin ortalamalarının alınması için konuya ilişkin bilirkişi incelemesi yaptırılması gerektiği belirtilmektedir.

\section{AŞKIN ZARARIN İSPATINDA DİKKATE ALINMASI GEREKEN İLKELER}

Aşkın zararın ispatında hangi yöntem uygulanırsa uygulansın hukukî tartışmaları sona erdirecek bir çözüm olmayacaktır ${ }^{58}$. Bu nedenle yöntemlere ilişkin genel ilkeler ve ilkelerin istisnalarının neler olduğunun belirlenmesi gerekir.

Uzun süren davalar nedeniyle para alacaklarının geç tahsil edilmesi sıkça karşımıza çıkan bir sorundur. Yıllardır meydana gelen kur artışları, enflasyon oranları, altın gibi emtiaların artış oranlarına bakıldığında paranın değer kaybettiği görülmektedir. $\mathrm{Bu}$ nedenle de zararın uygulanmasında hangi yöntemin uygulanacağının tespiti büyük önem taşımaktadır.

Zarar gören, zararını ispatlarken hangi yönteme dayandığını kendisi seçecektir. Zarar görenin yapacağ 1 bu seçim ilke kararları ile şekillendirilmelidir.

\section{A. Somut Yöntemin Uygulanması}

Somut yöntem, her borç ilişkisinde uygulanabilmesi mümkün olan bir yöntemdir. Alacaklının ispat zorluğu yaşayacağı bir yöntemdir. Bu yöntem niteliği gereğince, sözleşmeden kaynaklı para borçlarından kaynaklanan aşkın zarar iddiasına ilişkin davalarda uygulanması gereken yöntemdir.

Sözleşmeden doğan para borçlarından kaynaklı olarak aşkın zarar talep edildiğinde tazminat belirlenirken somut olayın özellikleri dikkate alınmalıdır. Şöyle ki, sözleşmeden doğan para borcu için vade kararlaştırılmışsa, her vadeli borç, alacaklı için zamanında ödenmeme riskini de içerir. Alacaklının, sözleşmenin kuruluşu aşamasında borçlunun ödeme kabiliyetini araştırmaması da tazminatın değerlendirilmesinde dikkate alınmalıdır. Tazminat belirlenirken, TBK md 114/f.2'nin yaptı̆̆ yollama gereğince, TBK md 51' de ifade edilen "mevcut durumun" özelliklerinin dikkate alınması gerekir. "Vadenin belirlenmesi", "borçlunun ödeme güçsüzlüğünün dikkate alınmaması" ve bunun gibi hususlar hükmedilecek tazminattan ayrı ayrı indirim sebebi yapılmalıdır. Alacaklının, temerrüde düşen borçluya uzun bir süre icra takibi yapmaması ya da dava açmaması da alacaklının kusuru olarak değerlendirilebileceğinden bu durum da TBK md 52 gereğince, "kusura" dayalı indirim yapılmasını gerektirir.

Somut yöntemin uygulanması konusunun iki farkını, aşağıdaki örnek üzerinden açiklayalım.

Birinci ihtimalde, A, evini, B' ye satmıştır. Yapılan anlaşma gereğince, A, B'ye tapuyu devredecektir ve B de tapu devrinden üç ay sonra A' ya 150.000 TL ödeyecektir. Temerrüt hâlinde de uygulanacak temerrüt faiz oranı, yürürlükte bulunan temerrüt faizi oranının iki katı olacaktır. A, B'ye tapuyu devretmiş olmasına rağmen, B ödemesi gereken parayı A' ya ödememiştir. Bunun için A, B'ye alacak davası açmış, dava altı yıl sürmüş ve sonunda A, B'den anaparayı ve işlemiş faizi tahsil etmiştir. A, temerrüt faizi ile karşılanamayan zararı olduğu iddiası ile B' ye dava

özelliği de dikkate alınarak, bulunacak miktarın TBK'nun 51 ve 52. (mülga BK'nun 42 ve 43.) maddeleri çerçevesinde değerlendirmeye de tabi tutularak belirlenmesi ve bundan sonra bulunan bu zarar miktarından asıl alacak tahsil edilirken alınan temerrüt faizi miktarı düşülerek hasıl olacak sonuç çerçevesinde davacı ...'nin munzam zararının olup olmadığ 1 ve miktarı tayin ve tespit edilmesi gerektiğinden..."

${ }^{57}$ Y. 15. HD., E. 2018/1494, K . 2019/932, T. 04.03.2019, (www.yargitay.gov.tr, ET:01.04.2020). “Öncelikle munzam zarar talep edilen alacakla ilgili temerrüt tarihinden tahsil tarihine kadar geçen süredeki enflasyon verilerini gösterir TEFE, TÜFE-ÜFE oranları, banka vadeli mevzuat faiz oranları, döviz kurları, devlet tahvil faiz oranları, işçi ücretleri ve diğer yatırım araçları ile ilgili getiri bilgilerinin resmi kurumlardan sorulup tespit edildikten sonra, yeniden oluşturulacak munzam zarar hesabı konusunda uzman bilirkişi kurulundan, tahsiline karar verilen davacılar alacağının temerrüt tarihinde bu yatırım araçlarından oluşacak sepete yatırılması ve değerlendirilmesi halinde tahsil tarihlerinde asıl alacakla birlikte getirisinin ulaşabileceği miktar ile tahsiline hükmedilen asıl alacak ve bu alacak için temerrüt tarihinden tahsil tarihlerine kadar davacıların tahsil edebilecekleri ve tahsil ettikleri faiz miktarı ve toplam miktar ve bu şekilde bulunacak toplam miktarlar arasındaki fark konusunda gerekçeli, mahkeme ve Yargıtay denetimine elverişli rapor alınıp değerlendirilerek faizle karşılanamayan zarar konusunda sonucuna uygun bir karar verilmesi yerine eksik inceleme ile davanın reddi doğru olmamış, kararın bozulması uygun bulunmuştur”.

${ }^{58}$ BUZ, s.406. 
açmıştır. Kanaatimizce, bu davada aşkın zararın varlığından söz edilebilmesi için taraflarca kararlaştırılan "özel temerrüt faiz" oranını aşan zararın varlığı gerekir.

İkinci ihtimalde A, evini B' ye vadeli olarak satmıştır. A, evini vadeli olarak sattı̆ğ için piyasa koşullarına göre iyi sayılabilecek bir fiyata B'ye satmış olduğunun kabulü gerekir. Aksi halde A'nın, evini vadeli olarak satma ihtimalî çok düşüktür. Yapılan sözleşme gereğince B, A'ya satış tarihinden bir yıl sonra 150.000 TL ödeyecektir. Ayrıca B, küçük esnaf olup ödeme kabiliyeti çok yüksek biri değildir. A, B' den olan alacağını zamanında alamamıştır ve bu nedenle de alacak davası açmıştır. Alacak davası, altı yıl sürmüş ve dava sonunda A, alacağını faizi ile birlikte tahsil etmiştir. Temerrüt faizi ile karşılanmayan zararı olduğu gerekçesiyle aşkın zarar davası açmıştır. A, aşkın zarar miktarını somut yönteme göre ispat etse bile, durumun özelliği dikkate alınarak tazminattan indirim yapılmalıdır. Satışın vadeli olması ve alacaklının, borçlunun sözleşme kurulurken ödeme kabiliyetini araştırmaması gibi hususlar mevcut durumun özelliği olarak değerlendirilip, tazminattan indirim sebepleri yapılabilir. Ayrıca alacaklıya kusur atfediliyorsa kusura dayalı olarak ayrıca bir indirim yapılabilmesi de mümkündür.

\section{B. Soyut Yöntemin Uygulanması}

Soyut yöntemin uygulanması hâlinde, aşkın zarar iddiası bilinen vakıalar aracılığıyla ispat edilebilir.

Soyut yöntemin her para alacağının geç ödenmesi hâlinde uygulanacağı kabul edilirse; hemen hemen her uzun süren dava sonucunda yeni bir dava da açılacak ve aşkın zarar talebi gündeme getirilecektir. Bu durum ticari hayatı olumsuz etkileyecek olup yargıda aşırı iş yüküne neden olacaktır. Ayrıca unutulmamalıdır ki; aşkın zararın hiçbir zaman temerrüt faizini, ille de enflasyon ya da devalüasyon oranına çıkarma amacı yoktur. Bu nedenle de soyut yöntemin uygulanmasında borcun kaynağı önemlidir.

Özellikle sözleşmeden doğan para borçlarından kaynaklanan aşkın zararlarda bu yöntemin uygulanmaması gerekir. Sözleşme, iradeye bağlı bir borç ilişkisidir. Konusu para olan bir sözleşmede alacakl1, borçlunun temerrüde düşme ihtimâlini, paranın ekonomik olumsuzluklar nedeniyle değer kaybedebileceğini öngörebilir ve kanun koyucunun belirlemiş olduğu faiz sistemini bilebilecek durumdadır.

Bu unsurların varlığına rağmen para borcuna ilişkin vadeli bir borç ilişkisi yaratılmışsa ve aşkın zarar iddiası ileri sürülüyorsa, aşkın zararın ispatında uygulanması gereken yöntem, soyut yöntem olmamalıdır. Aksi durumun varlığında para alacağının geç tahsilinden kaynaklanan her davadan sonra aşkın zarara ilişkin ayrı bir dava açılması söz konusu olur. Oysaki, aşkın zararın faiz sisteminin getirmiş olduğu olumsuz sonuçları giderme fonksiyonu yoktur. Sözleşmeden doğan para borcunun temerrüdünden dolayı eğer aşkın zarar iddiası ileri sürülmüşse zararın varlığı somut yönteme göre belirlenmelidir.

Sözleşmenin diğer tarafının kamu kurumları ya da bankalar gibi özel izin ve imtiyaza dayalı kurumlar olması halinde alacaklının temerrüt faizini aşan zararının varlığını soyut yönteme dayalı olarak ispat edebilmesi mümkün olmalıdır. Örneğin bankalar birer güven kuruluşudur. Bankanın borcunu zamanında ödememesi ve alacaklının bankadan alacağını tahsil etmesi için zaman harcaması durumunda eğer temerrüt faizini aşan zarar varsa bu zararın ispatında soyut yöntem uygulanmalıdır. Bu yöntemin uygulanmasının nedeni, alacaklının hayatın olağan akışı gereğince borçlunun şahsına duyduğu güvendir.

Yargıtay, uzun yıllardır genellikle soyut ispat yöntemini uygulamamaktadır. Anayasa Mahkemesi'nin 21.12.2017 tarihli ve 2014/2267 E. kararında kamu kurumundan para alacağını zamanında alamayan kişinin, uğradığı zararının ispatında soyut ispat yönteminin uygulanması gerektiği belirtildikten sonra Yargıtay Hukuk Daireleri arasında görüş ayrılıkları çıkmıştır. Görüş ayrılığının temel nedeni, ekonomik olumsuzlukların doğrudan aşkın zarara sebep olup olmadığından kaynaklanmaktadır. Kanaatimizce, sorunun çözümü için, somut ve soyut yöntemin hangi kriterlere uygulanacağını belirlemek gerekir. Soyut yöntem, alacaklının iradesi olmaksızın ortaya çıkan borç ilişkilerinde uygulanmalıdır. Alacaklının iradesine bağlı olmaksızın doğan borçlarda, alacaklının borçluyu seçme imkânı olmadığı gibi borç ilişkisinin içeriğini belirlemesi de mümkün değildir. Bu nedenle haksız fiilden, sebepsiz zenginleşmeden ve gerçek olmayan vekâletsiz iş görmeden doğan borçlardan kaynaklı aşkın zarar tazminatlarında uygulanmalıdır. Soyut yöntemin uygulanmasını bir örnek üzerinden açıklayalım. 
Bir ilçe belediyesi tarafından A'ya ait arsaya ilişkin kamulaştırma yapılmadan, arsa ilçenin yoluna katılmıştır. Bir diğer ifade ile A'nın taşınmazına kamulaştırmasız el atılmıştır. Kamulaştırmasız el atma tarihinin, 02.01.2006 olduğunu kabul edelim. A'nın, 03.01.2006 tarihinde dava açtığını, davanın 03.01.2016 tarihinde karara çıktığını, tazminatın 100.000 TL olarak belirlendiğini, dava tarihinden itibaren işleyecek yasal faiz ile davalıdan tahsiline karar verildiğini ve karar sonrasında hemen davalı ilçe belediyesinin ödemeyi yaptığını varsayalım. 3095 sayılı Kanun gereğince, dava tarihi ile paranın ödendiği dönem arasında yasal faiz oranı hiç değişmemiştir. Yasal faiz oranı, \%9' dur. On yılda işlemiş faiz oranı, toplam \%90'dır. A, temerrüt faizi ile karşılanmayan aşkın zararı olduğu gerekçesiyle dava açmıştır. Bay A'nın açtığı davada, "kamulaştırmasız el atmadan kaynaklanan tazminat bana dava tarihi itibariyle ödenseydi ben altın yatırımı yapacaktım"; demesine gerek var mıdır? Kanaatimizce, A'nın böyle bir iddiaya dayalı talepte bulunmasına gerek yoktur. "Ödenmesi gereken tazminat zamanında ödenmedi ve bu nedenle de temerrüt faizi ile karşılanmayan zararım var" demesi yeterli görülmelidir. A'nın bu talebi değerlendirilirken ekonomik veriler ayrı ayrı değerlendirilmeli ve ortalama bir artış oranı belirlenmelidir. $\mathrm{Bu}$ ortalama değer, temerrüt faizinden yüksekse aşkın zararın varlığı kabul edilmelidir. Hangi ekonomik verilerin değerlendirileceği hususu ekonomik bir sorun olduğundan mahkemece bilirkişi incelemesi yaptırılmalıdır. Bilirkişi raporunda dikkate alınması gereken ekonomik veriler, enflasyon, devalüasyon, TEFE- TÜFE oranları, asgari ücret artış oranı, altın vb emtia artış oranları, dikkate alınarak ortalama bir artış oranı belirlenmelidir.

\section{SONUÇ}

Para alacaklarının zamanında ifa edilmemesinden dolayı temerrüt faizi ile karşılanamayan zararlar ortaya çıkabilmektedir. Para borçlarında, temerrüt faizi ile karşılanamayan zararlar, aşkın zarar olarak ifade edilmektedir. Temerrüde düşen borçlu, temerrüde düşmede kusursuz olduğunu ispat ederse, bu zararı gidermekle yükümlü değildir.

Aşkın zararı, talep edenin ispat etmesi gerekir. Aşkın zararın ispatına yönelik olarak, somut ve soyut yöntem olmak üzere iki farklı yöntem vardır. Türk Yargısı'nda uzun yıllardır aşkın zararın genellikle somut yönteme dayalı olarak ispat edilmesi gerektiği belirtilmekteydi.

Anayasa Mahkemesi'nin 21.12.2017 tarihli ve 2014/2267 E. sayılı kararında, para alacağının mülkiyet hakkı kapsamında olduğu belirtilerek soyut yönteme dayalı olarak aşkın zararın ispat edileceği yönündeki ilke kararından sonra ispat yöntemleri konusunda Yargitay Hukuk Daireleri arasında görüş ayrılıkları çıkmıştır.

Aşkın zararı talep eden hangi yönteme dayalı olarak zararını ispat edeceğini kendisi belirler. Somut yönteme dayalı olarak zararın varlığını ispat etmek genellikle çok zordur. Soyut ispat yönteminde fiili karinelerden yararlanıldığı için ispat kolaylığı söz konusudur.

Soyut zarar yönteminin uygulanmasında dikkat edilmesi gereken temel husus, borcun kaynağıdır. Alacaklının iradesi aranmaksızın ortaya çıkan borç ilişkilerinde soyut yöntemin uygulanması gerekmektedir. Örneğin, kamulaştırmasız el atmadan kaynaklanan davalarda taşınmaz sahibinin iradesi aranmaksızın borç ilişkisi doğmaktadır. Kamulaştırmasız el atmadan kaynaklı tazminatın geç ödenmesi durumunda bedelin ödeninceye kadarki süreçte gerçekleşen enflasyonist etkilere taşınmaz sahibinin katlanmaması gerekir. Bu nedenle de taşınmaz malikinin aşkın zarara ilişkin iddiasını enflasyon artışı gibi fiili karinelerden yola çıkarak ispat edebilmesi mümkün olmalıdır.

Sözleşmeden doğan borçlarda soyut ispat yöntemi uygulanmamalıdır. Sözleşme, tarafların birbirine uygun irade beyanlarıyla kurulur. Sözleşme kurulurken taraflar, sözleşmeye konu edimi, vadeyi, sözleşmeye bağlı teminatları ve diğer birçok hususu belirleyebilirler. Her sözleşme beraberinde geç ifa riskini de taşır. Aksi durumun varlığında alacağın geç tahsiline sebep olan her borçluya karşı ayrıca aşkın zarar davası açılması durumu söz konusu olur. Bu durum ekonomik ilişkilerde belirsizliklere yol açabileceği gibi aşırı yargı yüküne de sebep olur. Oysaki, kanun koyucunun aşkın zararı düzenlemesinin nedeni, yürürlükte bulunan temerrüt faizi oranını enflasyon oranı seviyesine çıarmak değildir.

Sözleşmenin diğer tarafinın kamu kurumu ya da bankalar gibi özel izinle kurulmuş güven kuruluşları olması halinde; sözleşmenin diğer tarafının aşkın zarar iddiasını, soyut yönteme dayalı ispat edebilmesi mümkün olmalıdır. Bu tarz sözleşmesel ilişkilerde kamu kurumu veya banka 
gibi bir kuruluş ile borç ilişkisi kuranın, ifanın zamanında yerine getirilmesi yönündeki haklı beklentisi korunmalıdır.

Sözleşmeden doğan para borçlarından kaynaklı olarak aşkın zararın varlığı iddia edildiğinde somut yöntem uygulanabilir. Bu yöntem uygulanırken "durumun gereği” dikkate alınmalıdır. Bu nedenle de öncelikle sözleşmeden doğan bir borcun vadeye bağlanması hâlinde alacaklının üstlenmiş olduğu risk dikkate alınmalıdır. Diğer borç ilişkilerinden farklı olarak sözleşmesel ilişkilerde alacaklının çoğu zaman borçluyu seçme imkânı da vardır. Alacaklının borçluyu seçerken göstermiş olduğu dikkat ve özen de dikkate alınmalıdır. Ödeme güçlüğü çeken bir borçlu ile sözleşme yapan alacaklının, hayatın olağan akışı gereğince alacağını zamanında alamaması doğaldır ve dolayısıyla bu durum talep edilebilecek aşkın zarardan bir indirim sebebi olarak değerlendirilmelidir. Kanun koyucu, eBK'dan farklı olarak TBK'da temerrüt faizinin üst sınırının mevzuatta öngörülen temerrüt faizinin iki katı olabileceğini emredici olarak belirlemiştir. Yasal sınır çerçevesinde tarafların özel temerrüt faizi belirlediği durumda, aşkın zararın varlığından bahsedilmesi için belirlenen özel temerrüt faizini aşan zararın varlığı gerekir.

Haksız fiillerden, sebepsiz zenginleşmeden ve gerçek olmayan vekâletsiz iş görmeden doğan borç ilişkilerinde, kural olarak alacaklının iradesi aranmadığı için soyut yönteme dayalı olarak aşkın zarar belirlenebilir. Durumun gereğince de hesaplanan aşkın zarardan ancak somut verilere dayalı olarak indirim yapılabilir.

\section{KAYNAKÇA}

ALTAŞ, Hüseyin: "Munzam Zararda İspat Sorunu" AÜHFD, 50(1), 2001, s.121-130.

ANTALYA, Gökhan: Borçlar Hukuku Genel Hükümler, V(1,3), Seçkin Yayınevi, 2.Baskı, Ankara 2019.

ATAMER, Yeşim M./SANLI, Kerem Cem: "Borçlar Kanunu'ndaki Faiz Serbestisini Sınırlayan Hükümlerin Uygulama Alanı: Hukuk, Ekonomi ve Davranışsal Ekonomi Perspektifinden Bir İnceleme”, YD, 42(3), Temmuz 2016, s.397-460.

AYDOĞDU, Murat: “6098 sayılı Türk Borçlar Kanununda Faiz ile İlgili Düzenlemeler”, DEÜHF, 12(1), 2020, s.85-136.

AYRANCI, Hasan: Türk Borçlar Hukukunda Munzam Zarar, Yetkin Yayınları, Ankara 2006.

BARLAS, Nami: Para Borçlarının İfasında Borçlunun Temerrüdü ve Bu Temerrüt Açısından Düzenlenen Sonuçlar, Kazancı Kitap Ticaret A.Ş, İstanbul 1992.

BUZ, Vedat: "Karşılaştırmalı Hukukta Munzam Zararın İspatı", Yargıtay Dergisi, (3), 1998, s.369-410.

DUMAN, Özgür: "Enflasyon Karşısında Para Alacaklarının Korunması ve Mülkiyet", Uyuşmazlık Mahkemesi Dergisi, (12), 2018, s.401-462.

ERDOĞAN, İhsan: Borçlar Hukuku Genel Hükümler, Gazi Kitabevi, 4.Baskı, Ankara 2019.

EREN, Fikret: Borçlar Hukuku Genel Hükümler, 19.Baskı, Yetkin Yayınları, Ankara 2015.

HELVACI, Mehmet: Borçlar ve Ticaret Kanunu Bakımından Para Borçlarında Faiz Kavramı, Beta Yayınevi, İstanbul 2000.

KAYA, Aslan: “Adi ve Ticari İşlerde Faiz”, İ̈HFM, 54(1-4), 1994, s.347-366.

KILIÇOĞLU, Ahmet M: Borçlar Hukuku Genel Hükümler, 23. Bası, Turhan Kitabevi, Ankara 2019.

NOMER, Haluk: "Para Borcu Kavramı ve Para Borçlarının BK md 115/I Anlamında Aynı Cinsten Kabul Edilip Birbirleriyle Takas Edilebilirliği Problemi”, IÜHFM, LVII(1-2), 1999, s.241264.

OĞUZMAN, M.Kemal/ÖZ, Turgut: Borçlar Hukuku Genel Hükümler, C.I, 14.Bası, Vedat Kitapçılık, İstanbul 2016.

ÖÇAL, Akar, "Munzam Zarar" Eskişehir İktisadi ve Ticari İlimler Akademisi Dergisi, Ocak 1967, 3(1), s.144-158.

TEKINAY, Selâhattin Sulhi/AKMAN, Servet/BURCUOĞLU, Hâluk/ALTOP, Atilla: Borçlar Hukuku Genel Hükümler, 7.Bask1, Filiz Kitabevi, İstanbul 1993.

SEROZAN, Rona: "Para Alım Gücünün Düşmesine Bağlı Kayıpların Karşılanmasında Eşitsizlikler", İstanbul Üniversitesi Hukuk Fakültesi Mecmuası, C.20, 1996, s.41-48.

ZEYTINOĞLU, Erol: "Para Borçlarında Temerrüt Hallerinde Munzam Zarar", İstanbul Ticaret Üniversitesi Sosyal Bilimler Dergisi, (8), Güz 2005/2 s.253-263.

YAĞCI, Kürşad: "Anapara Faizi ve Temerrüt Faizine Üst Sınır Getiren TBK M.88 ve TBK M.120 Hükümlerinin Ticari Faizler (TTK M.8 ve TTK.M.9 Bakımından Uygulanabilirliği’,'IÜHFM, 71(2), 2013, s.421-437.

YAVUZ, Nihat: Borçlar Hukuku, Adalet Yayınevi, Ankara 2018. 